greater than the differences in types actually recognized; the detailed descriptions of the associations, community types, or habitat types are often quite comparable. Collation of the various classification units will be a major job for plant ecologists during the next few years.

A philosophical difference between the U.S. and Canada appears to be in the area of mapping. U.S. programs emphasize development of classifications that must and can be applied by the managers; maps are generally not available so the manager must be able to recognize the ecological site types in the field. Canadian programs generally include mapping and classifications are not oriented toward on-theground recognition of types by managers.

\section{References}

Becking, Rudolf Willem. 1954. site indicators and forest types of the Douglas-fir region of western Washington and Oregon. 133 p., illus. (Unpubl. Ph.D. thesis on file at Univ. Wash., Seattle.)

Carkin, Richard E., and Don Minore. 1974. Proposed harvesting guides based upon an environmental classification in the South Umpqua basin of Oregon. USDA For. Serv. Res. Note PNW-232, 8 p., illus. Pac. Northwest For. and Range Exp. Stn., Portland, Oreg.

Daubenmire, R. 1952. Forest vegetation of northern Idaho and adjacent Washington, and its bearing on concepts of vegetation classification. Ecological Monographs 22(3):301-330, illus.

Daubenmire, R., and Jean B. Daubenmire. 1968. Forest vegetation of eastern Washington and northern Idaho. West. Agric. Exp. Stn. Tech. Bull. 60, 104, p., illus.

Del Moral, Roger, Alan F. Watson, and Richard S. Fleming. 1976. Vegetation structure in the Alpine Lakes region of Washington State: classification of vegetation on granitic rocks. Syesis 9:291-316, illus.

Dyrness, C. T., Jerry F. Franklin, and W. H. Moir. 1974. A preliminary classification of forest communities in the central portion of the Western Cascades in Oregon. Coniferous For. Biome Bull. No. 4, 123 p., illus.

Franklin, Jerry F., C. T. Dyrness, and W. H. Moir. 1970. A reconnaissance method for forest site classification. Shirin Richi XII(1):1-14.
Hall, Frederick C. 1973. plant communities of the Blue Mountains in eastern Oregon and southeastern Washington. 62 p., illus. USDA For. Serv. Pac. Northwest Region R6 Area Guide 3-1.

Hawk, Glenn M. 1976. A comparative study of temperate Chamaecyparis forests. 195 p., illus. (Unpubl. Ph.D. thesis on file at Oreg. State Univ., Corvallis.)

Henderson, Jan Alan. 1973. Composition, distribution and succession of subalpine meadows in Mount Rainier National Park, Washington. 150 p., illus. (Unpubl. Ph.D. thesis on file at Oreg. state Univ., Corvallis.)

Hopkins, William E. 1976. Plant communities of south Chiloquin and Klamath Ranger Districts, Winema National Forest. 32 p., illus. + map. USDA For. Serv. Pac. Northwest Region R-6 Area Guide.

Long, James. 1976. Forest vegetation dynamics within the Abies amabilis zone of a western Cascade watershed. 174 p., illus. (Unpubl. Ph.D. thesis on file at Univ. Wash., Seattle.)

McNeil, Robert Curlan. 1975. Vegetation and fire history of a ponderosa pine-white fir forest in Crater Lake National Park. 171 p., illus. (Unpubl. M.S. thesis on file at Oreg. State Univ., Corvallis.)

Minore, Don. 1972. A classification of forest environments in the South Umpqua basin. USDA For. Serv. Res. Pap. PNW-129, 28 p., illus. Pac. Northwest For. and Range Exp. Stn., Portland, Oreg.

Spilsbury, R. H., and D. S. Smith. 1947. Forest site types of the Pacific Northwest. B. C. For. Serv. Tech. Publ. T.30, 46 p., illus.

Sullivan, Michael James. 1976. Stocking levels and seedling heights on clearcuts in relation to habitat type in the Western Cascades of Oregon. 81 p., illus. (Unpubl. M. S. thesis on file at Oreg. State Univ., Corvallis.)

Volland, Leonard A. 1976. Plant communities of the central Oregon pumice zone. 110 p., illus. USDA For Serv. Pac. Northwest Region R6 area Guide 4-2.

Waring, R. H. 1969. Forest plants of the eastern Siskiyous: their environmental and vegetational distribution. Northwest Sci. $43: 1-17$, illus.

Zobel, Donald B., Arthur McKee and Glenn M. Hawk. 1976. Relationships of environment to composition, structure, and diversity of forest communities of the central Western Cascades of Oregon. Ecol. Monographs 46(2):135-156, illus.

\title{
Improving the Logger's Image
}

\author{
George E. Percy ${ }^{1}$
}

Over the past few years I have been asked from time to time to speak on one topic or another. But, because I am not a speaker and do not feel comfortable speaking, I have agreed to do so only on topics in which I have an interest and feel I have some knowledge. If there was ever a topic falling into that category, it is the one you have chosen for discussion tonight, and it is gratifying to me to see the problem finally recognized and enunciated as well as it was in your circular.

In addressing tonight's subject - Improving the Logger's Image - I hasten to say that I have no instant solution to the problem. I will deal with what I believe to be the forces which collectively have created the problem, in the hope that this may help to turn the tide in the opposite direction.

Two sides of the image question must be considered one, the image in the world around him, and the other, the

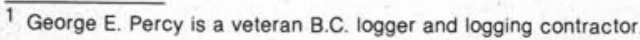

logger's own self-image. In my view, over the past three to four decades, the logger and his image have been increasingly victims of a changing society and a changing industrial structure. This has been due to two main forces: one, the world outside the timber industry and the other, the timber industry itself - with the most devastating results on the logger's own self image.

But before proceeding I would like to identify the type of man who historically has made a good logger . . . a type who still exists in our society but who no longer sees logging as a worthwhile endeavour to pursue. Through the years the logger has been a hard-working, innovative individual who is free-wheeling and free-spirited. He is satisfied only when he can see steady progress for his efforts, when the pay is tops for his type of work, and, in the case of the more ambitious ones, when the opportunity to progress exists. In addition, his pride requires that he work with a well-directed, highly productive crew in a well-planned, smooth-running opera- 
tion where he is treated as an equal by his supervisors. If any of these ingredients are missing, his pride and his independent nature force him to leave and seek them in some other endeavour, and this has been happening over the past few decades, to a far greater extent than we have been able to afford, or will be able to afford, in the future. Only technological development in our machines and methods have brought us through to this point, but I think the trend will have to be reversed in the future - we'll have to find some way to bring these guys back.

I know lots of people think we can run the logging industry without this type of man but I do not share this view especially if we are to have any degree of efficiency in the future. In any case, many of these people don't understand the significant, basic, fundamental fact that in the case of the mills the machines set the pace for the men and in the woods the men set the pace of the machines - a hell of a big difference!!

Moving to the forces of a changing society outside the industry which affect the logger and his image, it must first be said that our society has expanded so greatly over the past three or four decades that a whole new world of opportunities has been opened up for the type of men who make good loggers. These opportunities have welcomed them with open arms and better rewards than we have provided in the woods. It's time we started matching and bettering them in some manner.

This changing and expanding society has also created a whole new set of social values and priorities - some of them warped out of all proportion. The environmental and conservation movements, for example, begun for justifiable concerns, have been allowed to grow far beyond realistic proportions. They have become homes for many losers in our society, financed by over-paid movie stars looking for publicity and second and third generation inheritors of wealth, seeking a justification for their existence.

They have grown to such powerful proportions that they influence large segments of our society such as our school systems, finance the elections of vote hungry politicians and even presidents, and sway governments. There is no way the logger can fight this force alone. He will more likely say, "to hell with it" and go drill for oil or build pipelines or - in the case of B.C. - go work for the ferry system or some other attractive life in the service sector.

In my opinion, the timber industry, the forest service, and the three unions involved have failed to defend the logging industry and its loggers against these forces. If we are to keep the mills, we will continue to need logs and loggers to produce them, so they better get together and fight these people with equal force on their own ground

Turning to the industry itself, I would like to touch on four main areas which have had, and continue to have, a lot to do with the subject. I'll begin with the large timber corporations which, one way or another, employ most of us. The large corporation has developed in recent times throughout the western world for many reasons. Needless to say, the timber industry is no exception - where, added to reasons such as tax laws, worldwide trade, and competition, we have the long-term cost burden of sustained-yield forestry. The corporations have done a lot for the industry, including the logging sector; however, there appear to be two or three self-defeating characteristics common to most of them. The one which concerns us here is the fact that top management no longer has enough real knowledge of, or real interest in, the logging sector and its people.

Twenty or thirty years ago, most of the men at the very top of the timber companies were woods-oriented people. To name a few: H. R. MacMillan, Sid Smith, George O'Brien Sr., Don Denman, Sr., Bob Filberg, Walter Koerner, Gordon Gibson, Fred Brown, K. B. Fraser, Doane Hartnell and many others. These men were all different, but they had one thing in common and that was their understanding of logging and its needs, and loggers and their needs. During their times, although they were busy men, it was seldom that a month went by without their being seen and heard in their logging operations - looking the situation over for themselves and talking and listening to their people. Now they are all gone, leaving behind a vacuum which has been filled with boardroom philosophies and men who are rarely seen in the woods and therefore can't hope to understand.

I'm sure intentions have been good, but mistakes have been made from this level which have seriously hurt the logging sector, its loggers, and their image. This is particularly true in areas of labour negotiation and impractical finetuning of the logging sector over the years, which have left the logger the loser with a loss of faith in his industry. I think too that there is a silent philosophy emanating from the corporate level down, that loggers, including lower management, really shouldn't have anything. Perhaps I have become paranoid in my thinking on this subject and the fact that I have done fairly well myself could perhaps belie the point I'm making, but, nevertheless, I have this impression and I know it is shared by many others.

In any case, I think it's time that the logging sector be given more autonomy, responsibility and broader authority to run its own affairs. I also think it needs to be insulated to the greatest degree possible from the highs and lows of corporate thinking - particularly from fish-eyed controllers seeking to reduce inventories to impractical and dangerous levels - there are some huge monuments to such tampering. I think too, although I can't find anyone to agree with me, that labour negotiations in logging should be divorced completely from the mills. For too long the woods have been the battleground in the struggle between the unions and the corporations, with the logger coming out on the short end, particularly with respect to his stability of employment and his earning level. I'm pretty sure that if any or all of these changes are made a big step will have been made to improve the lot and the image of the logger.

Next on my list is the Forest Service, and here I want to say that I believe that we have probably the most outstanding Forest Service in the world. We must also recognize that our Forest Service has responsibilities to other sectors of society in our province, aside from the logging. However, sustained raw material supply for the timber industry is by far their greatest responsibility. We must recognize, too, that the Forest Service has also been a victim of a changing society and has suffered growing pains and has some shortcomings, which haven't helped the logging image.

For one, it has allowed itself to develop into a huge centralized bureaucracy which has had the effect of frustrating the logging sector and emasculating the district ranger, who since earliest times, has been a respected, decisive member of the logging group. There are signs of moves to correct this and there are also signs that once again the ranger may become the working partner of the logger, thus helping to improve the image of both.

The service is made up mainly of professional foresters and I have long been critical of that group - who rightfully should be the professional arm and lead in the timber industry - for taking too low a profile and not defending us as much as they should against outside forces. I think that the forestry profession in general and the Forest Service in particular should defend our industry and our loggers in the society around us with force and determination and thus defend and improve the image of the logger.

Next, our unions. The two pulp unions and the I.W.A. can probably do more to defend our industry and our people against our detractors than any other force if they choose to do so. The reason for this is their tremendous voting power and its attraction to politicians, as well as the influence in our communities through sheer numbers. In my opinion they have done next to nothing to defend our industry in the public eye. The exception to this, of course, is the effort of 
the I.W.A. in the Tsitika affair, which was probably the most impressive and influential representation made - an excellent example of what can be done.

I believe the three unions involved could and should unite and mount a resistance to our detractors and thus improve the lot and the public image of our people and our industry, and it is in their own long term interest to do so. I also believe that the I.W.A. has allowed itself to become too milloriented and is guilty, with the corporate leaders, of making the woods the battleground and loggers the losers in their struggles. Stability and well-being have been brought to the mills at the expense of the logging sector and sooner or later the piper will have to be paid. The handwriting is on the wall in the woods and the construction industry in the U.S. Having said that, I wish to make it clear to all, and to Wyman Trineer in particular, that I am in no way making cheap shots at the I.W.A. and I have nothing but respect for the I.W.A. as a responsible union and for most of its leaders for their responsible leadership.

Finally, I would like to touch briefly on the management group of the logging sector. When I first worked in the woods almost 47 years ago and for many years after, nearly everyone working there was a logger, and all worked together. Managers worked a large part of their time with the men in some way and even owners spent a good deal of time in the operations. With the coming of sustained yield this all began to change, with professional foresters, engineers and others slowly and steadily moving into management positions. This, in the final analysis, was a natural development. In the process, however, some mistakes were made which I think will sooner or later have to be corrected.

In the beginning there was a conflict between the new academically trained professional and the old hard-head logger, with the professional inevitably winning out, for understandable reasons. The unfortunate result of this, however, is the conclusion left in the minds of loggers that any logger short of a superman can no longer rise above the rank of woods foreman. This situation should be corrected for all to see because the best of these guys, with a little help, can be a much-needed part of the management team, and in any case, this policy is turning away a valuable group of people.

In some companies, they are filling all the management positions exclusively with one profession or another. This is an incestuous in-bred, self-defeating policy which can only hurt these people and the industry in the long run because it isn't only turning off much needed loggers, it is turning away many needed engineers as well. Engineers, like good production loggers, have attractive options in the world around us and are taking them rather than a restrictive secondary position in logging. In any case, a varied mix makes a healthier team in almost any context.

I think also that the so-called professionals moving into supervisory jobs have not troubled to get enough basic training in logging work and in understanding its people, and I think their supervisors are remiss in not insisting on this. I think that if this were mandatory, a better reciprocal understanding would develop to everyone's advantage. I have not intended to be critical of our senior logging management, because the fact is we have some very fine and capable men in that group. However, I have wondered from time to time if they have not perhaps functioned a little too much as gentlemen when representing our industry at the corporate level, and I have often wondered if we wouldn't be better off if they made like irate hooktenders once in a while. In any case, I have seen some of the old-timers mentioned earlier blow their stacks, with some impressive results, in defending the well-being of the logging industry.

Well, by this time, many of you will have concluded that here is another "has been", condemning everything around him ... and you could be right. But let me assure you that my intent is constructive and my opinions are the result of open-minded consideration of the problems over a period of many years. I really believe that the forces I have mentioned have created the problem of the logger and his image, and all concerned will have to unite to correct the problem for their own sakes.

Many will say, "What the hell is he talking about ... there is no problem, the logging operations are running and running well". I can only say that it is my firm conviction that we have a serious problem with people which is increasing and which will have to be corrected. I can only hope that the younger people are listening with interest to what I have to say, because those of us who are older are sometimes inclined to defend our mistakes and rationalize old positions. Increasingly people in the overall timber industry and the attendant society fail to realize that logging is a hard, dirty, dangerous and uncomfortable way to make a living. They do not understand that the logger has to put up with rain, snow, wind, steep terrain, brush, flies, heat, early morning shifts, long uncomfortable rides to and from work; in some cases, isolation from the amenities of modern life, and the risk of travelling back and forth in little planes; and all too often, is subject to sudden lay-off.

They do not understand that increasingly there are alternatives available to these people, which are more stable, better paying, and afford more opportunity for progress. They do not understand that we have made logging a second class occupation and that more and more loggers and potential loggers are moving to the alternatives. The do not realize that, since the beginning of time, loggers have dreamed of owning their own little show or rising to the top of their trade, or that, in any case, they were proud of being the highest paid skilled manual workers in the country, and that now all these doors appear to be closing. They do not seem to see that the core of steady experienced men in the industry, including supervisors and experienced engineers, is shrinking, that the average age level in this group is steadily rising, and that many are kept there only by a covert system of bribery. They do not seem to notice that, in spite of the fact that their operations have gone fairly smoothly over the last couple of years, and in spite of a $10 \%$ unemployment factor across Canada and a $30 \%$ unemployment factor in the B.C. construction industry over the same period, we have a dangerous shortage of good supervisors, engineers, skilled operators, mechanics, and fallers. That to me spells trouble, particularly in the light of the forecast labour shortage by the midale 80 's.

I have no formula for correcting the problems outlined; but I do believe that to get good men to return to the woods we are going to have to open the door of opportunity wider. And I would say that, by one formula or another, we are going to have to ensure that their net annual earnings are $10-20 \%$ higher than they would be in the alternatives available.

Perhaps small work groups which allow expense writeoffs and greater earnings for greater effort may be part of the answer, as it is to some extent in the Pacific Northwest states and the U.S. construction industry in recent times. But this won't work, either, if we continue the prevailing policy in this area whereby when money is made on one setting or mile of road, we try to take it away on the next.

In any case, I sincerely hope that the young people coming on will learn to understand these problems and will go on to correct them, because I do know this for sure .... the mills will continue to run and they will continue to need logs, and loggers to produce them. In the final analysis, log production and cost will be the top priorities and basis of final judgement, as they have always been, and heads will continue to roll for the same reasons. No grand illusions of silviculture or accounting will change these basic facts, so we had better get on with improving the lot and the image of the logger. 